\title{
RESIDENTIAL RELOCATION AND CHILDREN'S SATISFACTION WITH MASS HOUSING
}

\author{
Yücel Can SEVERCAN*
}

Received: 26.03.2018; Final Text: 06.11.2018

Keywords: Residential satisfaction; mass housing; urban regeneration; relocation; children.

\section{INTRODUCTION}

Especially since the endorsement of the "cities without slums" action plan at the UN Millennium Summit in September 2000, informal housing areas in developing parts of the world are being increasingly replaced by formal housing developments. Turkey is one such country where these transformations are occurring. A government report highlighted that between 2003 and 2013, the Mass Housing Administration of Turkey built approximately 481,000 mass housing units across the nation, 70,000 of which were constructed in the context of squatter housing regeneration (TOKI, 2013). This report announced that the number of mass housing units in Turkey is projected to increase to 1 million by the year 2023. Such trends raise concerns about the impact of these developments on the experiences and feelings of children, who are highly dependent on neighborhood environments because of their limited mobility (Woolley, 2006; Fyhri et al., 2011).

Although there is abundant literature discussing the impact of mass housing developments on the lives of adult mass housing tenants (Berkoz et al., 2009; Rowlands et al., 2009; Karaman, 2013; Dinç et al., 2014), no study has ever investigated the effects of relocation on children's satisfaction with mass housing. Part of the reason is that children have largely been ignored in quantitative research in general (Scott, 2000) and studies that examine young people's residential satisfaction in particular. This paper aims to contribute to the existing literature by addressing this gap.

The paper starts with a review of the concept of residential satisfaction and the literature on the factors that influence this construct among children.

Because a considerable number of studies on children's residential satisfaction were published before the 2000s, the author did not limit the review to papers published during a fixed period. Then, the paper describes an empirical study conducted in Ankara, Turkey, which aimed to 
understand the effects of relocation on 9-12 year old children's satisfaction with mass housing built in the context of squatter housing regeneration. Next, the paper asks whether, how and why children's residential satisfaction changed (or did not change) after moving to mass housing developments. It questions the role of various dwelling and neighborhood characteristics in this change. Data were obtained using a survey and a follow-up group interview. Some of the findings regarding children's satisfaction with their residential environments had not been discussed in the literature reviewed. The paper ends with the implications of the study results.

\section{Children's Residential Satisfaction and its Explanatory Characteristics}

Residential satisfaction is conceptualized as a measure of satisfaction with home and neighborhood (Galster, 1987; Kaitilla, 1993; Ogu, 2002). It is defined as the feeling of contentment that one achieves when one's actual and desired (or aspired) needs regarding his/her housing and neighborhood environment are met (Morris and Winter, 1978; Galster and Hesser, 1981; Mohit et al., 2010). When individuals assess their residential satisfaction, a subjective evaluation is made based on the characteristics of both home and neighborhood (Galster and Hesser, 1981). While a greater degree of congruence between actual and desired conditions reflects a higher residential satisfaction, incongruence leads to residential dissatisfaction (Michelson, 1977; Li and Wu, 2013).

Residential satisfaction is a multi-dimensional construct affected by many factors (like physical, social and personal) operating at the home, neighborhood and individual level (Ibem and Amole, 2013). Data obtained from children aged 6-18 in different culture and settlement conditions showed that a number of factors affect children's satisfaction with home. These include: the size, location, interior quality and architectural style of the dwelling; having one's own bedroom and a garden; presence/absence of a safe and social home environment with family and peers; buildings' construction quality; and place memories (Ladd, 1972; Homel and Burns, 1985; Devlin, 1994; Hadjiyanni, 2000; Loukaitou-Sideris and Stieglitz, 2002; Gifford, 2007; Severcan, 2012). Studies focusing on the role of dwelling location (van Vliet 1981; Loukaitou-Sideris and Stieglitz 2002) have shown that inner-city children are more likely to feel satisfied with their home because of the accessibility of commercial establishments (like grocers, bakeries and discount stores), and cultural facilities (like movie theatres and community centers), and dissatisfied due to inadequate maintenance of public spaces, noise, traffic and safety issues in the neighborhood. Suburban children are more likely to feel satisfied with their dwelling because they tend to find the area safe, quiet and accessible to recreational areas and scenic views, and less likely to feel satisfied if exciting and ageappropriate facilities are lacking in the home range. A review of "children's liked places" literature supports these findings by showing that children love to spend time in residential, public, commercial and recreational places that are safe, accessible, social, comfortable, green and fun (Moore, 1986; Castonguay and Jutras, 2009; Sancar and Severcan, 2010; Banerjee et al., 2014).

In this study, the term "place" is used to mean all kinds of physical settings like homes, playgrounds, grocers, streets, mass housing estates, neighborhoods and cities, and the human experiences associated with these settings (see Relph, 1976, Tuan, 1977; Massey and Thrift, 2003). In line with this definition, Lee at al. (1994) defined neighborhoods as social 
constructions named and bounded differently by different individuals (see also Tuan, 1975). Burton and Price-Spratlen (1999) supported this view by noting that children define their neighborhood more by associational and social relationship ties than by its spatial qualities (such as form) or political/administrative boundaries. As children grow up, their spatial range (and thus place experiences) increases, and, with this, comes a broader view of the extent of their neighborhood. Similarly, Min and Lee (2006) found that the boundaries of a neighborhood may vary from one child to another depending on the meanings ascribed to neighborhood settings and how well these settings are used.

There is a great deal of literature discussing the role of having good friends and neighbors and exclusion of undesirable people (like gangs, drunks, vandals) in promoting children's satisfaction with their environments (Loukaitou-Sideris and Stieglitz, 2002; Loukaitou-Sideris, 2003; Severcan, 2012). The provision of highly accessible, safe and well maintained public spaces is important because such places give children the opportunity to meet different people, play, get away from daily hassles and develop their problem-solving skills (Matthews, 2001; Hart, 2009). Thus, public spaces like streets and playgrounds are vital for children's development and well-being (Cooper Marcus and Sarkissian, 1986; Moore, 1986; Carr et al., 1992; Valentine, 1996; Freeman, 2010). In a study conducted in lowincome Istanbul neighborhoods with varying degrees of redevelopment, Severcan (2018) supported these arguments by showing that, although they lacked the infrastructure needed for a healthy life, children living in the least redeveloped neighborhoods were highly satisfied with their communities because of the existence of high-quality and highly-accessible neighborhood open spaces. This study also showed that children in more redeveloped neighborhoods were less likely than those in less redeveloped ones to pay attention to the social attributes of their communities (such as relatives' houses and streets as social spaces).

Research from the United States and Canada found that when economically disadvantaged families move from substandard low-rise apartment dwellings to high-rise public housing, they express mixedfeelings for their new residential environments (see, for example, Yancey, 1971; Michelson, 1977). Michelson (1977) showed that on the one hand they feel satisfied with the infrastructure of their apartments but on the other feel dissatisfied with their social lives since these apartments are occupied by poor families with a variety of social and health problems (like drug abusers, gang members, individuals with illness). Examining such a public housing project in Richmond (Washington, USA), Cooper Marcus (1975) found that because of the incidence of unruly behaviors and poorly maintained interiors and public open spaces, there were children who were ashamed of living in public housing, making them unwilling to bring their friends home from school to see where they lived. Gifford's (2007) study implies that children's social interactions are negatively affected when they move from low-rise to high-rise apartment buildings since parents living in such environments (especially in high-rises located in crime-prone neighborhoods) tend to keep their children indoors more. Therefore, forced relocation due to urban regeneration poses significant risks for residential satisfaction of children living in traditional and informal neighborhoods, especially in terms of social outcomes (van Vliet, 1986; Kleit and Manzo, 2006). 
The theory of residential satisfaction suggests that higher levels of satisfaction with the dwelling and neighborhood characteristics are associated with higher residential satisfaction among children. Relocation may influence children's residential satisfaction (positively or negatively) by altering their physical, social, cultural, political and economic environment, and hence their perception and assessment of the dwelling and neighborhood characteristics. Humke and Schaefer (1995) added that parents' attitude toward the move may influence children's assessment of their environments since children were found to mirror their parents' attitudes.

Individual factors may affect satisfaction with home and neighborhood, including age, education, income and length of stay in residence (Basolo and Strong, 2002; Chapman and Lombard, 2006; Mohit et al., 2010). Ibem and Amole (2013) have shown that such factors may either directly affect individuals' residential satisfaction or indirectly influence it by shaping people's place perception. However, only a few studies have addressed whether these factors have any effect on children's residential satisfaction. In a study conducted with children and adolescents, Schiavo (1990) found that age differences were more influential than gender differences. Chapman and Lombard (2006) showed that as age and income increase, individuals' response to neighborhood satisfaction tends to increase. In the informal settlements of China, $\mathrm{Li}$ and $\mathrm{Wu}$ (2013) found that prior living experiences affect people's residential satisfaction.

\section{Context of the Study: From Squatter Settlements to Mass Housing Estates in Ankara}

This article focuses on a study conducted in Ankara. Following its declaration as the capital of Turkey in 1923, Ankara became a magnet to immigrants. As the housing stock decreased, the immigrants built their own squatter dwellings (gecekondus), first in weakly controlled public lands surrounding the historic citadel, and later on the urban fringe (Uzun, 2005). Until the 1980s, due to the public sector's failure to provide housing, the growth of the squatter settlements continued in Ankara. Mahmud and Duyar-Kienast (2001) described these settlements as unplanned, homogeneous and compact developments, composed of physically similar one or two story structures with small gardens or courtyards. Over time, many of these informal developments were associated with poverty, poor infrastructure, lack of public amenities (like parks and playgrounds), crime and drugs, but also with a number of positive features, such as a strong sense of community and public life.

Especially after 2000, with the influence of neoliberal economic policies such as the loosening of controls on capital flows, deregulation and attraction of foreign investment, the Turkish Government started putting greater emphasis on the wholesale redevelopment of squatter neighborhoods (Karaman, 2013). Part of the policy agenda has been to enhance the image of cities and to brand them in international markets for tourism (Erendil and Ulusoy, 2002; Enlil, 2011). This encouraged planning approval for large-scale housing developments, state-of-the-art office buildings in city centers, shopping malls, culture and convention centers, museums, and luxury hotels and restaurants (Enlil, 2011). A related effect has been the view of squatter settlements as the source of social ills and health problems (like poverty, high crime rates and drug use), which needed to be transformed to open up fresh room for accumulation (Dündar, 2001; Karaman, 2013). Between 2004 and 2007, a 
series of laws were passed, granting local municipalities rights to execute urban transformation projects in collaboration with the Mass Housing Administration of Turkey (TOKI).

For squatter housing regeneration projects, TOKI adopted a propertyled redevelopment approach. This entails the forced removal of people from squatter settlements, the demolition of these areas and replacement with high-rise standardized apartments, which are usually constructed on the same site and at a higher density (Karaman, 2013). These mass housing units are then made available to displaced residents for purchase via mortgage loans and to the public at market prices. One can observe such developments across the country at a growing rate. In all these mass housing projects, TOKI uses a cookie-cutter design.

\section{METHOD}

\section{Site and Participant Selection}

This paper examined the effects of relocation on 9-12 year-old children's satisfaction with mass housing built in the context of squatter housing regeneration. The data was derived from a large-scale project aiming to investigate the relationships between children and mass housing. The author selected the project participants in five steps. First, in collaboration with officials from TOKI, four mass housing estates recently built (2008 and later) in Ankara were selected. Two of these estates were located in the inner-city (Altindag Gultepe TOKI and Mamak Yatikmusluk TOKI), while the other two were located in the outer-city (Altindag Karacaoren TOKI and Mamak Kusunlar TOKI).

The selected inner-city mass housing estates were near important functions of the city (like hospitals and manufactories). They were located within walking distance (300-350 meters) of each other and were still surrounded by squatter housing areas. Altindag Gultepe TOKI and Mamak Yatikmusluk TOKI were chosen from among a sample of four inner-city TOKI project areas because of their close proximity to the historic citadel of the city and the author's intention to involve as many children as possible in the project. There were no census data on the size of the child population in the mass housing estates in the country, and arguably, an estate with more housing units meant more children to participate in the study. The number of mass housing units in Altindag Gultepe TOKI and Mamak Yatikmusluk TOKI were 1448 and 528 respectively, making these two inner-city TOKI project areas larger than the other inner-city mass housing estates built in Ankara within the context of squatter housing regeneration.

There were only two outer-city estates that had been built in the context of squatter housing regeneration in the city, so the author selected both of them. Altindag Karacaoren TOKI was located on the north side of Ankara, close to the airport and the new luxury housing developments mushrooming along the northern highway corridor of the city.

Agricultural, partly forested lands and villages surrounded this outer-city development. Mamak Kusunlar TOKI was located on the south of the city and was surrounded by vast non-vegetated open lands, away from urban areas. The number of mass housing units in Altindag Karacaoren TOKI and Mamak Kusunlar TOKI were 1984 and 1374 respectively.

The selected sites had physical characteristics similar to many other TOKI's mass housing estates across the country (Figure 1). Buildings looked alike 
and were designed only for residential purposes. High-rise apartment buildings were arranged in superblocks separated by wide roads. While some apartments were clustered around small parks and playgrounds, others were grouped around large parking lots. Parks and playgrounds, located together, were places with few standard play equipment and sitting furniture. They rarely contained outdoor gym equipment and none had sports fields (like basketball courts). Supermarkets existed only in the outer-city mass housing developments. Although there were no supermarkets in the chosen inner-city estates, they were available in the vicinity of these developments along with some other land uses like traditional commercial establishments (for example, greengrocers, grocers, butchers and traditional coffee houses called "kahvehanes"), which typically are small establishments selling/serving only one category of product and being "full service" rather than self-service. A cultural center for children and youth (youth center) was available only in Altindag Karacaoren TOKI; child-oriented cultural establishments were lacking in the other selected sites. Vast lawns surrounded the apartment buildings in all project areas. The buildings consisted of 2-3 bedroom apartment units in the chosen inner-city mass housing estates and Altindag Karacaoren TOKI, and 2 bedroom apartment units in Mamak Kusunlar TOKI. All buildings included a number of interior design elements provided by TOKI: a kitchen cabinet, laminated floors, wooden doors and painted walls.

In the second step, the author chose all the public schools in the selected neighborhoods $(n=6)$. Third, the author gave a presentation describing the project in each classroom of third, fourth, fifth and sixth graders in the chosen schools. Scholars have found that children at these ages can often remember events they experienced in early childhood (Fivush et al., 1995; Quas et al., 1999). Fourth, the author asked the children who wanted to take part in the project to sign an assent form; parents approved their child's participation by signing a consent form. Lastly, the author selected all the children who wanted to participate in the study.

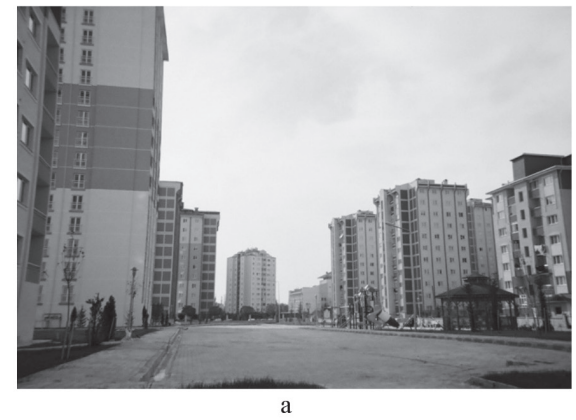

a

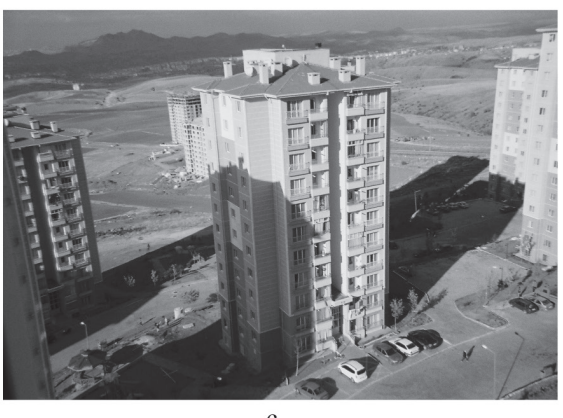

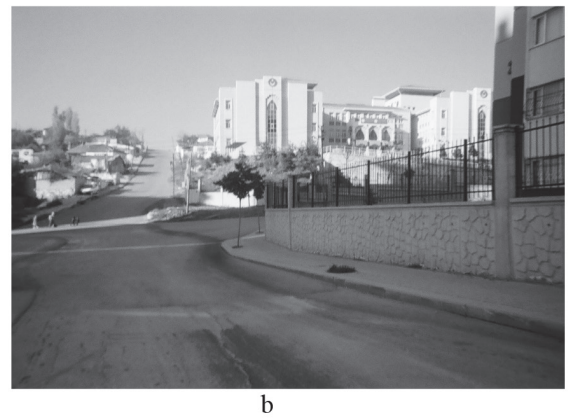

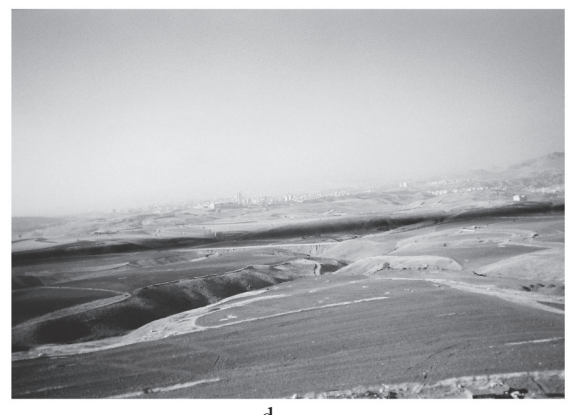

d
Figure 1. The selected mass housing estates were similar in most of their physical characteristics. One significant difference was the type of places surrounding these communities. a: A photograph from an inner-city mass housing estate (Mamak Yatikmusluk TOKI). b: Wide roads separate squatter housing areas from inner-city mass housing developments (Altindag Gultepe TOKI). c: A photograph from the selected outer-city mass housing estate (Mamak Kusunlar TOKI). d: Vast open
spaces surrounding the selected suburban development. 
Although the larger project took place in four mass housing estates in Ankara, for the purpose of this paper, which is partly about children's prerelocation place experiences, the data obtained from Altindag Karacaoren TOKI was not used in this study. This exclusion was necessary to minimize threats to the accuracy of the findings. After all the data was collected from the chosen estates, the author found that the average years of residency of the child participants from Altindag Karacaoren TOKI was more than 6 years. As suggested by Schroder et al. (2003), the farther away the recalled information is from the current time, the greater the likelihood of response inaccuracy and bias. Quas et al. (1999) revealed that children are more likely to incorrectly remember the emotions and experiences they had 3 years ago or more. Since the average years of residency of the child participants from Altindag Gultepe TOKI, Mamak Yatikmusluk TOKI (the two inner-city estates) and Mamak Kusunlar TOKI (the outer-city estate) was not more than 3 years, for the sake of accuracy, only the data obtained from these three estates were used in this study.

\section{Instrument}

This study is based on the results of a residential satisfaction survey and a follow-up group interview with children. Surveys and interviews are routinely used to obtain information from school-aged children (Driskell, 2002). However, developing an appropriate survey instrument for investigating the residential satisfaction of children aged 9 to 12 was challenging, since there were few existing empirical studies with young people on the topic. The author aimed to develop a simple instrument that was easily understood.

The survey was anonymous and separated into five main parts. The first and second parts were about the respondents' satisfaction with their previous home and neighborhood. Child respondents were asked to rate their overall satisfaction with their former residential setting on a five-point Likert scale ranging from one (not at all satisfied) to five (very satisfied). A "don't remember" response option was included. Additionally, children were asked to describe (in close-ended question format) the type of their previous dwelling (squatter house, multi-story apartment, single family housing, other), and (in open-ended question format) why they felt satisfied/dissatisfied with their previous home and neighborhood. The respondents were not asked to rate their level of satisfaction with a range of pre-defined characteristics associated with previous home and neighborhood (like the climatic comfort inside their previous home or the safety of street crossings in their previous neighborhood) due to a possible memory bias in the recall of early childhood experiences.

The third and fourth parts of the survey focused on children's assessment of their level of satisfaction with a range of current home and neighborhood characteristics (Table 4) and also their overall satisfaction with these places. In defining these characteristics, the author drew on the available literature related to both children's and adults' residential satisfaction (for example, Onibokun, 1974; Hadjiyanni, 2000; Berkoz et al., 2009; Ibem and Amole, 2013; Severcan, 2012). Again, these questions were asked using a five-point Likert scale ranging from one (not at all satisfied) to five (very satisfied). These parts also included questions about children's years of residency (YOR) in the current home, neighborhood and city, and open-ended questions about any other things that made respondents feel satisfied/dissatisfied with their environment. The final part of the survey asked respondents to describe their socio-demographic characteristics. All 
Likert scale questions were presented in a visual analogue scale to facilitate the comprehension of the response options and open a window for the use of parametric tests.

Referring to studies on children and neighborhood (for example, Burton and Price-Spratlen, 1999; Min and Lee, 2006; Freeman, 2010), the term neighborhood was explained to children as a place that includes all the settings that are readily accessible to them on foot. The author emphasized that it may include settings that are (1) favored/important but not used well, (2) used well but not favored/important, (3) favored/important and used well, and (4) not favored/important and not used well settings (see Min and Lee, 2006). Accordingly, the child participants were informed that the current neighborhood includes places that are located not only inside but also outside the vicinity of their mass housing estates provided that they are readily accessible. It was important to consider accessible places that were located outside the mass housing estates as part of children's neighborhood environments for two main reasons. First, three of the visited public schools were located outside the chosen (inner-city) estates, approximately 5-10 minutes walking distance from children's home. Children attending these schools were frequently exposed to various people, activities and land uses outside their estates (such as squatter housing, traffic, gangs and grocers), which might influence their residential satisfaction. Second, all of the selected estates were surrounded by a number of places (like urban streets, schoolyards, friends/relatives' houses or vast non-vegetated open spaces) that were highly accessible and also possibly liked/disliked and frequently/rarely used by children, thus, affecting children's evaluation of their mass housing environments (see Castonguay and Jutras, 2009; Sancar and Severcan, 2010; Severcan, 2012).

In a second meeting, children were group interviewed to validate survey responses and reveal more information about the effects of relocation on children's residential satisfaction. Each group consisted of approximately 15 children. The interviews were semi-structured and lasted approximately 1.5 hours. The children were asked: How would you describe your previous home - was it a squatter housing, a high-rise apartment building or other? Before moving to the mass housing, did you like your previous home and neighborhood, and why? How would you describe the environment that you aspire to live in? Do you think that your current environment has the qualities of the environment that you aspire to live in, and why? Do you like your current home and neighborhood, and why? One of the key findings from the survey study was (...); do you agree with this, and why? To increase the accuracy of recall, participants were guided by questions that helped them reconstruct the context of their previous/ current home and neighborhood experience (for example, "Could you describe what that place looked like?" or "What activities were you doing there?"). Probes were used whenever necessary.

During the interviews, the author encouraged each participant to respond to each question. Because some participants did not agree to the use of an audio recorder, as children expressed their ideas, the author recorded all the comments on a large easel pad. This was done without any identifying information so that the respondents can view them, express their opinions without any social pressure, and confirm whether the statements were recorded fully and correctly. As children raised new themes/comments, they were coded under a new node. Finally, to draw general conclusions from these data, the author kept track of how many children agreed or disagreed with these themes. 
Table 1. Socio-demographic characteristics of research participants.

\begin{tabular}{|c|c|c|c|c|c|c|}
\hline & \multicolumn{6}{|c|}{$\begin{array}{l}\text { Children } \\
(\mathrm{N}=137)\end{array}$} \\
\hline & \multicolumn{3}{|c|}{ Inner-city } & \multicolumn{3}{|c|}{ Outer-city } \\
\hline & $\mathrm{n}$ & $\%$ & M & $\mathrm{n}$ & $\%$ & M \\
\hline \multicolumn{7}{|l|}{ Age } \\
\hline $9-12$ & 63 & $46 \%$ & 10.52 & 74 & $54 \%$ & 9.62 \\
\hline \multicolumn{7}{|l|}{ Gender } \\
\hline Male & 26 & $41.2 \%$ & & 34 & $45.9 \%$ & \\
\hline Female & 37 & $58.8 \%$ & & 40 & $54.1 \%$ & \\
\hline \multicolumn{7}{|l|}{ Mean YOR in } \\
\hline Current home & & & 3.2 & & & 2.64 \\
\hline Current neighborhood & & & 5.11 & & & 2.74 \\
\hline Current city & & & 9.06 & & & 8.59 \\
\hline \multicolumn{7}{|c|}{$\begin{array}{l}\text { Type of the previous place of } \\
\text { residence }\end{array}$} \\
\hline Squatter housing & 21 & $33.3 \%$ & & 37 & $50 \%$ & \\
\hline Multi-story apartment & 37 & $58.7 \%$ & & 33 & $44.6 \%$ & \\
\hline Single family dwelling & 5 & $8 \%$ & & 4 & $5.4 \%$ & \\
\hline
\end{tabular}

\section{Analysis}

The analysis presented here is based on the survey and group interview responses of 137 children aged 9-12 living in three mass housing estates. The number of children from inner- and outer-city mass housing estates was 63 and 74 respectively. Table 1 shows the socio-demographic composition of the survey participants by location. Of the 137 child respondents, 60 were male and 77 were female; 58 said that they had previously lived in squatter housing, while 79 were in a non-squatter housing area (hereafter formal neighborhood). The respondents' mean YOR in home was 2.9 years $(S D=1.32)$. This indicates that response inaccuracy and bias associated with remembering the previous place of residence were not significant given the findings of Quas et al. (1999), who reported that children interviewed within 3 years of an event provide more correct information about it compared to those who were interviewed 3 or more years after the event.

The effects of relocation on children's overall satisfaction with home and neighborhood were examined using a paired t-test. To understand why children's satisfaction changed (or did not change) after relocation, the responses to the open-ended questions were content analyzed. To this end, the author began by reviewing the data closely. Segments of text were coded and then grouped into similar themes, which were later grouped into larger categories. Finally, the author compared the themes associated with the previous and current place of residence. To increase the validity of the results, these themes were compared with the group interview responses. 
Table 2. Mean residential satisfaction scores of children before (pre) and after (post) relocation.

\begin{tabular}{l|cccc|ccccc}
\hline & \multicolumn{4}{|c|}{ Home } & \multicolumn{5}{c}{ Neighborhood } \\
& Pre & Post & $\mathrm{t}$ & $\mathrm{p}$ & Pre & Post & $\mathrm{t}$ & $\mathrm{p}$ \\
\hline Overall satisfaction & 3.68 & 3.90 & 1.53 & .12 & 3.74 & 3.45 & 1.52 & .13 \\
Moved from squatter housing & 3.48 & 3.88 & 1.70 & .09 & 3.51 & 3.38 & .41 & .67 \\
Moved from non-squatter housing & 3.80 & 3.89 & .68 & .49 & 3.89 & 3.48 & 2.09 & $.03^{*}$ \\
Moved to inner-city mass housing & 3.18 & 4.10 & 3.12 & $.00^{*}$ & 3.41 & 3.27 & .60 & .54 \\
Moved to suburban mass housing & 3.92 & 3.73 & .76 & .44 & 4.01 & 3.59 & 1.65 & .10 \\
\hline
\end{tabular}

Note. * Statistically significant difference between the mean pre- and post-mean residential satisfaction scores $(p<.05)$.

\section{RESULTS}

\section{Effects of Relocation on Children's Satisfaction with Home}

Overall, the mean post-relocation residential satisfaction scores of the children $(n=137)$ were not significantly different from their mean prerelocation residential satisfaction scores at the home level $(t=1.53, p>.05)$ (Table 2). However, satisfaction with home significantly increased among children who had moved to an inner-city mass housing estate $(t=3.12, p<$ .05). No statistically significant change was observed in the residential satisfaction scores of children who had moved to the outer-city. Similarly, moving from squatter or non-squatter housing had no significant affect on children's satisfaction with home.

\section{Residential Relocation and Factors Affecting Children's Satisfaction with Home}

The survey results show that, of the 137 children, only 8 did not explain why they felt satisfied/dissatisfied with their previous home. As Table 3 illustrates, after moving to mass housing, the reasons for children's satisfaction/dissatisfaction with their dwelling changed. An important finding is that after relocation, children started to pay more attention to the physical rather than the social attributes of their home. This finding is most poignant when it is observed that while 36 children mentioned the existence of "liked people" (such as having many friends and good neighbors) in the neighborhood as a factor contributing to their satisfaction with previous home, only 4 children tied their satisfaction with current home to this attribute. This result supports Kleit and Manzo (2006) and van Vliet's (1986) argument that relocation poses risks for children's residential satisfaction in terms of social outcomes.

Children explained their satisfaction with previous home largely by mentioning the following dwelling and neighborhood characteristics: having a house with a garden $(n=31)$, flowers and trees in the yard $(n=22)$, informal outdoor play areas $(\mathrm{n}=17)$ and commercial establishments (like grocer, bakery and supermarket) in the home range $(n=17)$. However, when asked about the reasons for their satisfaction with current dwelling, children largely talked about the interior features of their houses. Four of the six most mentioned positive factors affecting children's satisfaction with current home were: dwelling size, beauty of the views from windows, heating system and quality of the interior design (Table 3). Table 4, which shows the mean satisfaction scores for the current dwelling and neighborhood characteristics, supports these findings. The three most liked feature of the current dwelling were: level of brightness or light in 
Previous Place of Residence

Current Place of Residence

Home Level

Positive Factors

1. Having many 'liked people' (e.g., friends, neighbors) 1 . Having a house with many rooms $(n=10)$ in the neighborhood $(n=36)$

2. Having a house with many rooms $(n=32)$

3. Having a house with a garden $(n=31)$

4. Having flowers/trees in the garden $(n=22)$

5. Having informal outdoor play areas $(n=17)$

6. Close proximity to commercial areas $(n=17)$

2. Close proximity to parks/playgrounds $(n=9)$

3. Having pleasant views from windows $(n=7)$

4. Having visually attractive building exteriors $(n=7)$

5. Having a house with good heating $(n=6)$

6. High-quality interior spaces $(n=5)$

Negative Factors

1. Infrastructure problems of housing $(n=21)$

2. Having a house with few rooms $(n=20)$

3. Inaccessible parks/playgrounds $(n=12)$

4. Poor housing construction $(n=10)$

5. Having 'undesirable people' (e.g., drug users, gangs) in the neighborhood $(n=9)$

6. Poorly maintained open spaces $(n=9)$

Neighborhood Level

Positive Factors

1. Having many 'liked people' (e.g., friends, neighbors) in the neighborhood $(n=49)$

2. Close proximity to parks/playgrounds $(n=26)$

3. Having strong social ties in the neighborhood $(n=21)$

4. Close proximity to commercial areas $(n=21)$

5. Having a house with a garden $(n=14)$

6. Having many outdoor play areas $(n=12)$

1. Close proximity to parks/playgrounds $(n=14)$

2. Close proximity to commercial areas $(n=9)$

3. Having many 'liked people' (e.g., friends, neighbors) in the neighborhood $(n=9)$

4. Close proximity to school $(n=5)$

5. Living in a clean apartment building $(n=5)$

6. Having a beautiful scenery $(n=5)$

\section{Negative Factors}

1. Inaccessible parks/playgrounds $(n=17)$

1. Lack of outdoor sports areas $(n=17)$

2. Having 'undesirable people' (e.g., drug users, gangs) in the neighborhood $(n=13)$

3. Presence of people (e.g., neighbors/peers) swearing and fighting with each other $(n=11)$

4. Poorly maintained open spaces $(n=9)$

5. Inaccessible school buildings $(n=8)$

6. Poor housing construction $(n=7)$

2. Presence of people (e.g., neighbors/peers) swearing and fighting with each other $(n=9)$

3. Lack of large and well equipped parks and playgrounds $(n=8)$

4. Living in an unsafe area (e.g., lack of security guards, exposure to careless police officials) $(n=8)$

5. Inaccessible public transportation $(n=8)$

6. Poorly maintained open spaces $(n=6)$ 


\begin{tabular}{|c|c|c|c|}
\hline Characteristics & $\begin{array}{l}\text { Overall } \\
\mathrm{M}(\mathrm{SD})\end{array}$ & $\begin{array}{l}\text { Inner-city M } \\
\text { (SD) }\end{array}$ & $\begin{array}{l}\text { Outer-city M } \\
\text { (SD) }\end{array}$ \\
\hline \multicolumn{4}{|l|}{ Dwelling } \\
\hline Dwelling size* & $3.85(1.38)$ & $4.14(1.17)$ & $3.60(1.50)$ \\
\hline $\begin{array}{l}\text { Housing type (e.g. high-rise versus low-rise, detached versus } \\
\text { attached building, multi-story apartment versus one-to-three } \\
\text { story house with a yard) }\end{array}$ & $3.69(1.36)$ & $3.72(1.33)$ & $3.67(1.39)$ \\
\hline External appearance of the dwelling from outside & $3.77(1.31)$ & $3.89(1.21)$ & $3.68(1.39)$ \\
\hline $\begin{array}{l}\text { Appearance of interior design elements provided by the mass } \\
\text { housing administration (kitchen cabinet, doors, painted walls } \\
\text { and laminated floors) }\end{array}$ & $3.97(1.25)$ & $4.04(1.07)$ & $3.92(1.40)$ \\
\hline $\begin{array}{l}\text { Construction quality (the stability/sound insulation capacity of the } \\
\text { walls, doors and windows and the quality of the materials used } \\
\text { for finishing: condition of plasters/bathroom tiles) }\end{array}$ & $3.59(1.35)$ & $3.51(1.35)$ & $3.67(1.35)$ \\
\hline Level of brightness or light in the house during the daytime & $4.16(1.13)$ & $4.16(1.12)$ & $4.16(1.15)$ \\
\hline $\begin{array}{l}\text { Climatic comfort inside the home (i.e. feeling cool in summer and } \\
\text { warm in winter) }\end{array}$ & $3.97(1.29)$ & $3.93(1.27)$ & $4.01(1.31)$ \\
\hline Scenery viewed from the house & $3.83(1.42)$ & $3.63(1.51)$ & $4.00(1.32)$ \\
\hline $\begin{array}{l}\text { Efficiency of the housing management and administration (e.g. } \\
\text { whether caretakers keep the building clean, collect garbage } \\
\text { regularly, and whether the housing administration provides } \\
\text { periodic inspection and maintenance of elevators) }\end{array}$ & $3.15(1.49)$ & $2.93(1.49)$ & $3.34(1.47)$ \\
\hline \multicolumn{4}{|l|}{ Neighborhood } \\
\hline Proximity to school from home & $3.61(1.43)$ & $4.03(1.25)$ & $3.25(1.49)$ \\
\hline $\begin{array}{l}\text { Quality of the school (e.g. quality of its teachers, facilities, heating } \\
\text { infrastructure) }\end{array}$ & $3.58(1.38)$ & $3.52(1.34)$ & $3.63(1.43)$ \\
\hline Proximity, quality and quantity of shopping places & $3.11(1.43)$ & $2.92(1.34)$ & $3.28(1.48)$ \\
\hline $\begin{array}{l}\text { Proximity, quality and quantity of cultural places (e.g. theatres and } \\
\text { art galleries) }\end{array}$ & $2.67(1.60)$ & $2.50(1.55)$ & $2.81(1.63)$ \\
\hline $\begin{array}{l}\text { Proximity, quality and quantity of open spaces like picnic areas, } \\
\text { outdoor sports areas, parks and playgrounds }\end{array}$ & $3.22(1.51)$ & $3.08(1.57)$ & $3.35(1.46)$ \\
\hline Quantity of greenery (i.e. quantity of trees, grass and flowers) & $3.25(1.47)$ & $3.03(1.41)$ & $3.43(1.51)$ \\
\hline External appearance of buildings in the neighborhood & $3.46(1.33)$ & $3.24(1.37)$ & $3.65(1.28)$ \\
\hline $\begin{array}{l}\text { Building types in the mass housing estate (e.g. presence of high- } \\
\text { rise versus low-rise and detached versus attached buildings) }\end{array}$ & $3.34(1.37)$ & $3.09(1.39)$ & $3.54(1.33)$ \\
\hline Continuity, width and comfort of the sidewalks for walking & $3.44(1.44)$ & $3.31(1.40)$ & $3.54(1.47)$ \\
\hline Safety of street crossings & $3.14(1.36)$ & $2.82(1.32)$ & $3.40(1.35)$ \\
\hline Speed and number of cars using the local streets & $3.17(1.44)$ & $2.85(1.43)$ & $3.43(1.40)$ \\
\hline Proximity of public transportation stops to the home & $3.78(1.29)$ & $3.44(1.37)$ & $4.06(1.15)$ \\
\hline $\begin{array}{l}\text { Frequency of public transportation vehicles passing through the } \\
\text { neighborhood }\end{array}$ & $3.18(1.42)$ & $2.84(1.33)$ & $3.47(1.44)$ \\
\hline $\begin{array}{l}\text { Number of public transportation routes servicing the } \\
\text { neighborhood }\end{array}$ & $3.36(1.34)$ & $3.06(1.31)$ & $3.62(1.33)$ \\
\hline
\end{tabular}




\begin{tabular}{|c|c|c|c|}
\hline Characteristics & $\begin{array}{l}\text { Overall } \\
\mathrm{M}(\mathrm{SD})\end{array}$ & $\begin{array}{l}\text { Inner-city M } \\
\text { (SD) }\end{array}$ & $\begin{array}{l}\text { Outer-city M } \\
\text { (SD) }\end{array}$ \\
\hline $\begin{array}{l}\text { Number of 'liked or good people' (e.g. good friends, relatives and } \\
\text { neighbors) }\end{array}$ & $3.62(1.30)$ & $3.46(1.34)$ & $3.75(1.26)$ \\
\hline $\begin{array}{l}\text { Strength of social ties in the neighborhood (e.g. whether neighbors } \\
\text { greet and visit each other) }\end{array}$ & $3.79(1.22)$ & $3.49(1.35)$ & $4.04(1.04)$ \\
\hline $\begin{array}{l}\text { Presence and number of trusted people in the neighborhood who } \\
\text { can help or protect children in the absence of parents }\end{array}$ & $3.94(1.16)$ & $4.03(1.03)$ & $3.86(1.26)$ \\
\hline $\begin{array}{l}\text { Care taken by neighbors to protect the environment and keep it } \\
\text { clean }\end{array}$ & $2.73(1.54)$ & $2.50(1.45)$ & $2.93(1.60)$ \\
\hline $\begin{array}{l}\text { Level of sense of community (i.e. whether people act together or } \\
\text { help each other when they face common problems) }\end{array}$ & $3.17(1.41)$ & $2.82(1.37)$ & $3.47(1.37)$ \\
\hline $\begin{array}{l}\text { Number of people using the open spaces (e.g. streets and } \\
\text { playgrounds) }\end{array}$ & $3.58(1.32)$ & $3.38(1.39)$ & $3.75(1.24)$ \\
\hline $\begin{array}{l}\text { Perception of feeling safe in open spaces during the day and at } \\
\text { night }\end{array}$ & $2.69(1.56)$ & $2.44(1.50)$ & $2.90(1.59)$ \\
\hline $\begin{array}{l}\text { Adequacy of the measures taken for mitigating safety issues like } \\
\text { thefts, purse snatching and drug dealing }\end{array}$ & $2.50(1.58)$ & $2.25(1.47)$ & $2.71(1.65)$ \\
\hline $\begin{array}{l}\text { Quality of the municipal services (e.g. trash collection, street } \\
\text { cleaning, and water, electricity and sewage services) }\end{array}$ & $3.30(1.42)$ & $3.14(1.28)$ & $3.43(1.52)$ \\
\hline Level of air pollution & $3.49(1.38)$ & $3.31(1.25)$ & $3.64(1.47)$ \\
\hline Noise level of the neighborhood & $3.03(1.46)$ & $2.84(1.41)$ & $3.20(1.48)$ \\
\hline
\end{tabular}

Table 4 (continued)

Note. * Statistically significant difference between the mean residential satisfaction scores of inner- and outer-city children ( $\mathrm{p}<$ $.05)$. the house during the daytimes $(M=4.16, S D=1.13)$, appearance of interior design elements provided by the mass housing administration (like painted walls, kitchen cabinet, laminated floors and doors $)(M=3.97, S D=1.25)$ and climatic comfort inside the home $(M=3.97, S D=1.29)$.

In group interviews, children validated their responses on the questionnaire. One child who moved from a squatter settlement described her previous home as follows:

"I was living in a squatter dwelling. It had a large garden with many fruit trees and flowers. I loved climbing the trees and watering the flowers. I also had many friends in the neighborhood. We used to play in the garden all the time." (A girl from an inner-city mass housing estate)

Another child added:

"Now, there are lawns next to our apartment buildings. However, the housing administration does not allow children to step on the grass. We are not allowed to play on the lawns!" (A boy from an inner-city mass housing estate)

When asked about the play spaces in their neighborhood, many children mentioned their home as among the few areas available to children for playing.

Children's responses to the question about the environments they aspire to live in support these findings. Except for a few children in each chosen neighborhood, consistent with the findings of Hadjiyanni (2000), all children indicated that they wished they could live in one or two story houses with gardens that contain trees, flowers and a pool. A few children mentioned that the high-rise nature of their current dwellings and the scenes they view from windows match the qualities of the dwellings they 
aspire to live in. Children stated that they liked two things in particular about the views seen from their windows: the order they see in the arrangement of the buildings and the presence of lawns surrounding their dwellings. Additionally, a few children in the outer-city mentioned that they loved watching the city lights appearing on the horizon from their apartments.

Children who moved from formal neighborhoods described their previous home largely by referring to locational forces (such as close proximity to traditional commercial establishments like grocers and bakeries), whereas those who moved from informal neighborhoods mostly talked about their memories associated with informal outdoor play areas, such as house gardens and streets. Arguably, the lack of such public spaces and traditional commercial establishments in mass housing developments might be one of the reasons why children rarely mentioned the existence of friends or social activities as the reasons for their satisfaction with current dwelling. This may also explain children's increased attention to the interior qualities of their home.

In general, children had positive feelings for the size of their current dwelling $(M=3.85, S D=1.38)$ as they had for their previous home. However, there was a statistically significant difference between inner- and outer-city children's mean satisfaction scores with respect to dwelling size ( $t=2.30$, $p<.05)$. Compared to children in the outer-city, children in the inner-city estates were more satisfied with the size of their current home. This was perhaps because, as mentioned earlier, some inner-city children were living in apartment buildings with more rooms. In interviews, a few children supported this result by indicating that they wish they lived in larger dwellings with more rooms; in general, this aspiration was more likely expressed by children in the outer-city estate than the children in the innercity estates. No statistically significant difference was observed between inner- and outer-city children with respect to other dwelling characteristics listed in Table 4. Children's appreciation of the proximity of parks and playgrounds in their current home range (Table 3) was an expected outcome because of the way TOKI's mass housing projects are designed.

Some negative factors were highly mentioned repeatedly for both the current and previous home: having a house with few rooms and having undesirable people in the neighborhood. In the interviews, most participants emphasized that the latter was a major problem affecting their sense of safety, and hence their place satisfaction. Additionally, there were some negative factors, which contributed to children's dissatisfaction with current but not with previous home. One such problem was noise (sounds of car horns, gun-shots and fights). An interesting finding obtained from surveys and interviews is that noise and safety issues were mentioned equally often by both inner- and outer-city children. This result contradicts with the findings of Loukaitou-Sideris and Stieglitz (2002) and van Vliet (1981). However, it is reasonable since TOKI's regeneration approach enables the relocation of all homeowners (including gangs and people with behavior disorders) from squatter settlements to mass housing no matter where they are built, and all the selected developments shared similar urban design qualities.

Other highly mentioned negative factors that affected children's satisfaction with current, but not with previous, home are the inefficiency of housing administration and maintenance (like malfunctioning elevators and poorly maintained apartment buildings), lack of balconies and 
storage areas and playgrounds having broken play equipment (Table 3). The former was the least appreciated compared to the other pre-defined dwelling characteristic $(M=3.15, S D=1.49)$.

One thing that did not change in children's explanations after relocation concerns the buildings' construction quality. In interviews, children reemphasized this problem. "Because of the poor construction quality and poor workmanship of the buildings, my family renovated the interior of the home, and that's why I'm highly satisfied with the interior quality of the dwelling" said a child living in the suburban estate, and many others agreed including those living in inner-city areas. No children mentioned that they aspire to live in dwellings with better construction materials and workmanship, arguably because living in such dwellings might not be in the prime interest of children. As expected, housing infrastructure issues (like leaking sewage pipes and inadequate sanitary facilities), which were frequently mentioned for the previous residential area, were not mentioned at all for the current home (Table 3).

\section{Effects of Relocation on Children's Satisfaction with Neighborhood}

Overall, the mean post-relocation residential satisfaction scores of the 137 children were not significantly different from the mean pre-relocation residential satisfaction scores at the neighborhood level $(t=1.52, p>.05)$. However, as Table 2 illustrates, previous place experiences affected children's satisfaction with neighborhood. Although moving from a squatter settlement to a mass housing estate had no statistical influence on children's residential satisfaction ( $t=.41, p>.05)$, satisfaction with neighborhood decreased significantly among those who moved from a non-squatter housing area $(t=2.09, p<.05)$. Moving to an inner- or outer-city location did not influence children's satisfaction with neighborhood.

\section{Residential Relocation and Factors Affecting Children's Satisfaction with Neighborhood}

Of the 137 children, 127 explained why they felt satisfied/dissatisfied with previous and current neighborhood. The results show that after relocation significantly fewer children mentioned that they had many friends and strong communal ties in their neighborhood (Table 3). Despite this, after relocation, the importance of having friends continued to be one of the top three most mentioned factors affecting children's neighborhood satisfaction. As Table 4 illustrates, compared to other pre-defined neighborhood characteristics, children gave higher satisfaction scores for the level of social ties $(M=3.79, S D=1.22)$ and number of trusted people (other than parents) in the vicinity $(M=3.94, S D=1.16)$. Results from the interviews supported the survey findings. Children indicated that they had many friends and relatives in their previous neighborhood, but they had some good friends and relative in their current environment as well.

Unlike what was found out from children's explanations regarding their satisfaction with previous neighborhood, no children mentioned that they were satisfied with their current neighborhood because of the existence of informal outdoor play areas (Table 3). Streets with commercial establishments, alleys and/or home gardens once contributed to children's neighborhood satisfaction. After relocation, in the absence of such places, it appears that highly controlled and regulated public spaces like schools, parks and playgrounds became some of the few places where children could interact with the public, hence contributing to their residential satisfaction. 
The survey and group interview results revealed that a number of factors negatively influenced children's appreciation of outdoor environments in mass housing. Sense of safety was one of the most influential ones. For example, in interviews, when asked about the role of building types in children's satisfaction with mass housing, a child responded:

"The problem of mass housing is not about how the buildings look from outside or whether we live in high-rise apartments or not. It is more about the people living here and their actions. People are very rude. They fight, shout and often use a bad language. They litter and break the park furniture." (A girl, who moved from a non-squatter settlement to an innercity mass housing estate)

"They [the gangs] once threatened me with a knife and asked for money when I was headed to school" said a boy living in one of the inner-city mass housing estates. The author heard such comments from both boys and girls. Gangs involved in racketeering, vandalism and drug selling, and lack of responsible and powerful police officers in the environment were mentioned as among the most important problems decreasing children's satisfaction with mass housing in both surveys and group interviews. Table 4 supports these results by showing that, from a list of 17 neighborhood characteristics, the most disliked characteristic of the current neighborhood was the inadequacy of measures taken to mitigate safety concerns $(M=2.50$, $S D=1.58$ ). Although there was no significant difference between the way inner- and outer-city children assessed their neighborhood regarding this barrier $(t=1.69, p>.05)$, children who moved from non-squatter neighborhoods were more likely than the others to mention safety related issues in their neighborhoods. Regardless of the location of the current estate or where they had moved from, many children reported that they viewed their neighborhood open spaces unsafe $(M=2.69, S D=1.56)$. In interviews, some children emphasized that because of the safety issues they could not hang out, unsupervised, at public open spaces. Accordingly, they voiced their aspiration to live in safer environments.

After relocation, children continued to relate their neighborhood satisfaction to the existence of accessible parks and playgrounds. However, they also noted that these places in mass housing are too small, many of them have broken equipment and furniture, and they do not contain outdoor sports areas (Table 3 ). Some children in the inner-city stated that in the absence of sports areas in the mass housing estate, they were using the local streets outside their estates or the schoolyards for playing football or skating, but that safety issues in the neighborhood (such as gangs and speeding cars) restrict their access to and use of these places. Thus, when children were asked about the places they aspire to live in, all children indicated that they would like to live in a neighborhood with accessible, safe and well-maintained parks, playgrounds and outdoor sports areas (like football fields, basketball courts and skate parks).

As expected, inaccessibility of cultural places (like theatres and culture centers) was mentioned as an important factor negatively affecting children's neighborhood satisfaction both in surveys $(M=2.67, S D=1.60)$ and interviews since there were no such places in the selected estates. Thus, in all the selected neighborhoods, children stated that they aspire to live in a neighborhood that provides social and cultural attractions for children, such as places that offer music and art classes, sports activities and camping programs. Survey results suggest that children do not see the quality and quantity of commercial areas as an important problem in the 
current neighborhood (Table 3), (Table 4), but interview results revealed that this appreciation is merely a result of the existence of supermarkets in the neighborhood. In interviews, all children mentioned that they would like to see more commercial establishments (such as grocers, stationary stores, restaurants and coffee shops) in their neighborhoods.

Children in inner-city estates were significantly more likely to feel satisfied with the accessibility of their school than children in outer-city estate $(t=3.25, p<.05)$. In interviews, children living in outer-city estates explained that since their school is located on a steep slope, access to it requires great effort. Despite this issue, as shown in Table 3, after relocation, children's access to school generally increased. Furthermore, children in outercity estate were significantly more likely to feel satisfied with the social ties and level of sense of community in the neighborhood than children in inner-city estates ( $t=2.68$ and $t=2.74, p<.05)$. This might be because, compared to the selected outer-city estate, inner-city estates tend to be more gentrified due to the availability of well-paid work places in the vicinity (like hospitals). Moreover, as expected, outer-city children were significantly more likely to feel satisfied with the traffic volume on their local streets $(t=2.36, p<.05)$, and therefore, safety of the streets for crossing $(t=2.52, p<.05)$ than inner-city children, which is in line with the results of earlier studies (see van Vliet, 1981; Sancar and Severcan, 2010). Compared to children in the outer-city estate, children in inner-city estates were significantly more likely to feel dissatisfied with the frequency of public transportation vehicles passing through the neighborhood, the number public transportation routes that service the neighborhood and location of the public transportation stops $(t=2.64,2.44$ and 2.88, $p<.05$ for all).

\section{CONCLUSION}

The expansion of mass housing in developing countries poses a growing concern among both academics and the public about the impact of these developments on their inhabitants' well-being (Berkoz et al., 2009; Urban, 2012; Adebayo and Iweka, 2014; Dinç et al., 2014). Little is known about how children's residential satisfaction is influenced by moving to mass housing. The present study aimed to contribute to the existing literature in two ways. First, it provides a theoretical framework to understand how residential relocation might affect children's residential satisfaction. Second, by focusing on the mass housing estates that were built in the context of squatter housing regeneration in a developing county, Turkey, it questioned whether, how and why children's residential satisfaction changed after relocation.

Results showed that, overall, children's satisfaction with dwelling and neighborhood did not change after moving to mass housing. However, contributing to the results of earlier studies (for example, $\mathrm{Li}$ and $\mathrm{Wu}$, 2013; Loukaitou-Sideris and Stieglitz, 2002; van Vliet, 1981), this article showed that children's previous place experiences and the location of the current estate had an impact on their satisfaction with mass housing. While satisfaction with dwelling significantly increased among children who moved to inner-city estates, no change occurred among children who moved to the outer-city estate. Satisfaction with neighborhood significantly decreased among children who moved from a non-squatter housing area, whereas no change occurred among children who moved from a squatter settlement. A decrease in neighborhood satisfaction scores was observed 
among the children who moved to both inner- and outer-city estates, but this change was not statistically significant.

Children's explanations about why they were satisfied/dissatisfied with their previous and current place of residence provided an explanation for these results. It was shown that children's appreciation of some dwelling and neighborhood characteristics increased after relocation: heating system, quality of the interior design, housing infrastructure, and accessibility of parks, playgrounds, supermarkets and schools. In general, children's satisfaction with other dwelling and neighborhood characteristics either decreased (for example, with access to informal play spaces, traditional commercial establishments) or remained constant (for example, with building's construction quality). Regardless of their current location, all children complained that their current neighborhoods lack access to traditional commercial establishments (like grocers, stationary stores, restaurants and coffee shops), child-oriented cultural places (like cultural centers that offer social and cultural activities for young people) and parks and playgrounds with diverse activity spaces and equipment. Similarly, noise and safety were issues experienced by children in all contexts. Accordingly, children indicated that they aspire to live in places having accessible, safe and well-maintained neighborhood environments with a variety of public open spaces as well as cultural and commercial places that cater to their interests.

After relocation, children continued to have good friends and relatives in the vicinity. Nevertheless, it was also found that children's social networks were larger in their previous neighborhood, supporting the results of van Vliet (1986). Perhaps because of this and some other reasons like the loss of home gardens and high-quality public open spaces, compared to the results obtained for the previous neighborhood, children in the selected developments were likely to pay more attention to the physical than the social attributes of their current neighborhood. This result supports previous findings that have examined children's place experiences in neighborhoods with varying degrees of redevelopment (Severcan, 2018). Similarly, after relocation, in line with the findings of Cooper Marcus (1975) and Michelson (1977), children who moved from squatter settlements to an inner- or outer-city location, continued to express their concern about safety issues in the neighborhood. Compared to their feelings for the previous neighborhood, children who moved from a non-squatter settlement were more dissatisfied with the safety of the current neighborhood. These results suggest that by giving the local residents of squatter settlements an opportunity to buy/rent a unit in mass housing estates, TOKI's property-led redevelopment enables partial survival of community ties in regeneration processes on the one hand, and continuation of social problems, such as vandalism, assaults and drug use, on the other. The way mass housing developments are designed contributes to the growth of these problems.

\section{Implications for Urban Design}

Because similar mass housing schemes are still being constructed all over Turkey, the results of this study could guide urban planners and designers in their efforts to build communities that are loved by children. First, results suggest that to increase children's residential satisfaction in mass housing, planners and designers need to put greater emphasis on providing high-quality public open spaces. Integrating the existing land use system with commercial and cultural uses that support the public 
realm (like grocers, greengrocers, restaurants, coffee shops, theatres and cultural centers for young people) and spatially and functionally diverse parks and playgrounds that attract children's needs and expectations could be an important means to this end.

Second, planners and designers should put greater focus on increasing children's sense of safety. Children's interview responses imply that it is possible to mitigate this issue by addressing not only social and service delivery issues in the community (such as maintenance of public open spaces and policing), but also through urban design. There is voluminous literature discussing ways to design safer neighborhoods (Hillier, 2004; Loukaitou-Sideris, 2006; Nasar et al., 2015; Severcan, 2018). Based on the contextual attributes of the selected developments and data obtained from children, the author argues that adoption of some of these strategies may lead to an improved sense of safety, and thus, greater residential satisfaction among children. These could include increasing the land-use mix, joining buildings together, decreasing the building height, decreasing the road widths, improving crosswalks and using technology such as emergency phones and surveillance cameras in public spaces.

As this study has once again showed, the quality of the interior features of a dwelling and the availability of accessible, safe and attractive public spaces in the home range are of primary importance in promoting children's dwelling and neighborhood satisfaction. Therefore, in contexts where children's independent mobility is restricted, improving the quality of such places seems to be more important than improving the quality of places that are not readily accessible to children or that do not meet children's needs and expectations.

One question raised by this study is whether there should be a difference between the way inner- and outer-city mass housing developments are designed to promote children's residential satisfaction. The results presented here seem to suggest that because children encounter different potentials and barriers to their residential satisfaction in different locations (like proximity to traditional commercial establishments and crime-prone areas), the design of mass housing projects should likewise be different. Defining the urban design policies for inner- and outer-city mass housing developments requires a context-sensitive design approach in which researchers investigate which dwelling and neighborhood characteristics determine children's residential satisfaction in different locations.

\section{ACKNOWLEDGEMENTS:}

This work is supported by two grants: the Scientific and Technological Research Council of Turkey (TUBITAK) [114C056] and Middle East Technical University [BAP-08-11-2016-041]. The author would like to thank referees for their valuable comments and suggestions and Anita L. Akkas for her editing.

\section{BIBLIOGRAPHY}

ADEBAYO, A.K., IWEKA, A.C. (2014) Dwelling Space Deficits in Nigeria's Large Cities: Evaluation of Mass Housing Units in Lagos, Architecture Research 4(1A) 27-33.

BANERJEE, T., UHM, J.A., BAHL, D. (2014) Walking to School: The Experience of Children in Inner City Los Angeles and Implications for Policy, Journal of Planning Education and Research 34(2) 123-40. 
BASOLU, V., STRONG, D. (2002) Understanding the Neighborhood: From Residents' Perceptions and Needs to Action, Housing Policy Debate, 13(1) 83-105.

BERKOZ, L., TURK, Ş.Ş., KELLEKCİ, Ö. (2009) Environmental Quality and User Satisfaction in Mass Housing Areas: The Case of Istanbul, European Planning Studies 17(1) 161-74.

BURTON, L.M., PRICE-SPRATLEN, T. (1999) Through the Eyes of Children: An Ethnographic Perspective on Neighborhoods and Child Development, Cultural Process in Child Development: The Minnesota Symposia on Child Psychology, Volume 29 ed. A.S. Marten, Psychology Press, New York; 77-96.

CARR, S., FRANCIS, M., RIVLIN, L.G., STONE, A.M. (1992) Public Space, Cambridge University Press, New York.

CASTONGUAY, G., JUTRAS, S. (2009) Children's Appreciation of Outdoor Places in a Poor Neighborhood, Journal of Environmental Psychology 29(1) 101-9.

CHAPMAN, D.W., LOMBARD, J.R. (2006) Determinants of Neighborhood Satisfaction in Fee-Based Gated and Non-Gated Communities, Urban Affairs Review 41(6) 769-99.

COOPER MARCUS, C. (1975) Easter Hill Village: Some Social Implications of Design, The Free Press, New York.

COOPER MARCUS, C., SARKISSIAN, W. (1986) Housing as if People Mattered, University of California Press, Berkeley.

DEVLIN, A.S. (1994) Children's Housing Style Preferences: Regional, Socioeconomic, Sex, and Adult Comparisons, Environment and Behavior 26(4) 527-59.

DİNÇ, P., ÖZBILLEN, E., BİLİR, M.B. (2014) A Multi-Dimensional Scale for Measuring Residential Satisfaction (RS) in Mass Housing Projects, Indoor and Built Environment 23(6) 864-80.

DRISKELL, D. (2002) Creating Better Cities with Children and Youth: A Manual for Participation, Earthscan, London.

DÜNDAR, Ö. (2001) Models of Urban Transformation: Informal Housing in Ankara, Cities 18(6) 391-401.

ENLİL, Z.M. (2011) The Neoliberal Agenda and the Changing Form of Istanbul, International Planning Studies 16(1) 5-25.

ERENDİL, A.T., ULUSOY, Z. (2002) Reinvention of Tradition as an Urban Image: The Case of Ankara Citadel, Environment and Planning B: Planning and Design 29(5) 655-72.

FIVUSH, R., HADEN, C., ADAM, S. (1995) Structure and Coherence of Preschoolers' Personal Narratives Over Time: Implications for Childhood Amnesia, Journal of Experimental Child Psychology 60(1) 32-56.

FREEMAN, C. (2010) Children's Neighborhoods, Social Centres to 'Terra Incognita', Children's Geographies 8(2) 157-76.

FYHRI A., HJORTHOL, R., MACKETT, R.L., FOTEL, T.N., KYTTÄ, M. (2011) Children's Active Travel and Independent Mobility in Four 
Countries: Development, Social Contributing Trends and Measures, Transport Policy 18(5) 703-10.

GALSTER, G.C. (1987) Identifying the Correlates of Dwelling Satisfaction: An Empirical Critique, Environment and Behavior 19(5) 537-68.

GALSTER, G.C., HESSER, G.W. (1981) Residential Satisfaction: Compositional and Contextual Correlates, Environment and Behavior 13(6) 735-58.

GIFFORD, R. (2007) The Consequences of Living in High-Rise Buildings, Architectural Science Review 50(1) 2-17.

HADJIYANNI, T. (2000) Children and Their Housing - Insights from the Island of Cyprus, Housing and Society 27(2) 19-30.

HART, R. (2009) Charting Change in the Participatory Settings of Childhood, Children, Politics and Communication: Participation at the Margins, ed. N. Thomas, The Policy Press, Bristol; 7-30.

HILLIER, B. (2004) Can Streets Be Made Safe?, Urban Design International 9(1) 31-45.

HOMEL, R., BURNS, A. (1985) Through a Child's Eyes: Quality of Neighborhood and Quality of Life, Living in Cities: Urbanism and Society in Metropolitan Australia, eds. I. Burnley, J. Forrest, Allen and Unwin, Sydney; 103-15.

HUMKE, C., SCHAEFER, C. (1995) Relocation: A Review of the Effects of Residential Mobility on Children and Adolescents, Psychology: A Journal of Human Behavior 32(2) 16-24.

IBEM, E.O., AMOLE, D. (2013) Residential Satisfaction in Public Core Housing in Abeokuta, Ogun State, Nigeria, Social Indicators Research 113(1) 563-81.

KAITILLA, S. (1993) Satisfaction with Public Housing in Papua New Guinea: The Case of West Taraka Housing Scheme, Environment and Behavior 25(4) 514-45.

KARAMAN, O. (2013) Urban Renewal in Istanbul: Reconfigured Spaces, Robotic Lives, International Journal of Urban and Regional Research 37(2) 715-33.

KLEIT, R.G., MANZO, L. (2006) To Move or Not to Move: Relationships to Place and Relocation Choices in HOPE VI, Housing Policy Debate 17(2) 271-308.

LADD F.C. (1972) Black Youths View Their Environments: Some Views of Housing, Journal of the American Institute of Planners 38(2) 108-16.

LEE, B.A., OROPESA, R.S., KONAN, J.W. (1994) Neighborhood Context and Residential Mobility, Demography 31 249-70.

LI, Z., WU, F. (2013) Residential Satisfaction in China's Informal Settlements: A Case Study of Beijing, Shanghai, and Guangzhou, Urban Geography 34(7) 923-49.

LOUKAITOU-SIDERIS, A., STIEGLITZ, O. (2002) Children in Los Angeles Parks: A Study of Equity, Quality and Children's Satisfaction with Neighborhood Parks, Town Planning Review 73(4) 467-88. 
LOUKAITOU-SIDERIS, A. (2003) Children's Common Grounds: A Study of Intergroup Relations Among Children in Public Settings, Journal of the American Planning Association 69(2) 130-43.

LOUKAITOU-SIDERIS, A. (2006) Is it Safe to walk? Neighborhood Safety and Security Considerations and Their Effects on Walking, Journal of Planning Literature 20(3) 219-32.

MAHMUD, S., DUYAR-KIENAST, U. (2001) Spontaneous Settlements in Turkey and Bangladesh: Preconditions of Emergence and Environmental Quality of Gecekondu Settlements and Bustees, Cities 18(4) 271-80.

MASSEY, D, THRIFT, N. (2003) The Passion of Place, A Century of British Geography, eds. R. Johnston, M. Williams, Oxford University Press, Oxford; 275-99.

MATTHEWS, H. (2001) Children and Community Regeneration, Save the Children, London.

MICHELSON, W. (1977) Environmental Choice, Human Behavior, and Residential Satisfaction, Oxford University Press, New York.

MIN, B., LEE, J. (2006) Children's Neighborhood Place as a Psychological and Behavioral Domain, Journal of Environmental Psychology 26 51-71.

MOHIT, M.A., IBRAHIM, M., RASHID, Y.R. (2010) Assessment of Residential Satisfaction in Newly Designed Public Low-Cost housing in Kuala Lumpur, Malaysia, Habitat International 34(1) 18-27.

MOORE, R. (1986) Childhood's Domain: Play and Place in Child Development, Routledge, London.

MORRIS, E.W., WINTER, M. (1978) Housing, Family and Society, John Wiley, New York.

NASAR, J.L, HOLLOMAN, C., ABDULKARIM, D. (2015) Street Characteristics to Encourage Children to Walk, Transportation Research Part A: Policy and Practice 72 62-70.

OGU, V.I. (2002) Urban Residential Satisfaction and the Planning Implications in a Developing World Context: The Example of Benin City, Nigeria, International Planning Studies 7(1) 37-53.

ONIBOKUN, A.G. (1974) Evaluating Consumer's Satisfaction with Housing: An Application of a Systems Approach, Journal of the American Institute of Planners 40(3) 189-200.

QUAS, J.A., GOODMAN, G.S., BIDROSE, S., PIPE, M.E., CRAW, S., ABLIN, D.S. (1999) Emotion and Memory: Children's Long-Term Remembering, Forgetting, and Suggestibility, Journal of Experimental Child Psychology 72(4) 235-70.

RELPH, E. (1976) Place and Placelessness, Pion, London.

ROWLANDS, R., MUSTERD, S., VAN KEMPEN, R., eds. (2009) Mass housing in Europe: Multiple faces of development, change and response, Palgrave MacMillans, Basingstoke.

SANCAR, F.H., SEVERCAN, Y.C. (2010) Children's Places: Rural-Urban Comparisons Using Participatory Photography in the Bodrum Peninsula, Turkey, Journal of Urban Design 15(3) 293-324. 
SCHIAVO, R.S. (1990) Children's and Adolescents' Designs of Ideal Homes, Children's Environments Quarterly 7(4) 37-46.

SCHRODER, K.E.E., CAREY, M.P., VANABLE, P.A. (2003) Methodological Challenges in Research on Sexual Risk Behavior: II. Accuracy of SelfReports, Annals of Behavioral Medicine 26(2) 104-23.

SCOTT, J. (2000) Children as Respondents: The Challenge of Quantitative Research, Research with Children: Perspectives and Practices, eds. P. Christensen, A. James, Falmer Press, London; 98-135.

SEVERCAN, Y.C. (2012) Children's Attachment to Public Space in the Context of Urban Regeneration: Effects of Children's Involvement in Planning and Design Activities, unpublished Ph.D. dissertation, University of Colorado at Denver.

SEVERCAN, Y.C. (2018) Changing Places, Changing Childhoods: Regeneration and Children's Use of Place in Istanbul, Urban Studies 55(10) 2179-96.

TOKI (T.C. BAŞBAKANLIK TOPLU KONUT İDARESİ BAŞKANLIĞI) (2013) TOKI Corporate Profile 2012-2013. Building Turkey of the Future: Towards 1,000,000 Housing Units, TOKI, Ankara.

TUAN, Y.F. (1975) Place: An Experiential Perspective, Geographical Review 65(2) 151-65.

TUAN, Y.F. (1977) Space and Place: The Perspective of Experience, University of Minnesota Press, Minneapolis.

URBAN, F. (2012) Tower and Slab: Histories of Global Mass Housing, Routledge, New York.

UZUN, C.N. (2005) Residential Transformation of Squatter Settlements: Urban Redevelopment Projects in Ankara, Journal of Housing and Built Environment 20(2) 183-99.

VALENTINE, G. (1996) Children Should Be Seen and Not Heard: The Production and Transgression of Adult's Public Space, Urban Geography 17(3) 205-20.

VAN VLIET, W. (1981) Neighborhood Evaluations by City and Suburban Children, Journal of the American Planning Association 47(4) 458-66.

VAN VLIET, W. (1986) Children Who Move: Relocation Effects and Their Context, Journal of Planning Literature 1(4) 403-26.

WOOLLEY H. (2006) Freedom of the City: Contemporary Issues and Policy Influences on Children and Young People's Use of Public Open Space in England, Children's Geographies 4(1) 45-59.

YANCEY, W.L. (1971) Architecture, Interaction, and Social Control: The Case of a Large-Scale Public Housing Project, Environment and Behavior 3(1) 3-21. 
Alınd1: 26.03.2018; Son Metin: 06.11.2018 Anahtar Sözcükler: Konut memnuniyeti; toplu konut; kentsel dönüşüm; yerdeğiştirme; çocuk.

\section{YERDEĞİŞTİRME VE TOPLU KONUTLARDA YAŞAYAN ÇOCUKLARIN KONUT MEMNUNIYETI}

Bu makalenin amacı, gecekondu dönüşüm kapsamında üretilen toplu konut projelerine taşınan çocuklarda, yerdeğişimin çocukların konut memnuniyetine etkilerini araştırmaktır. Çalışma sonuçları, Ankara'daki üç toplu konut proje alanından çalışmaya katılan 137 adet 9-12 yaş grubu çocukların doldurduğu bir ankete ve grup söyleşilerine dayanmaktadır. Çalışma sonuçları, şehir dışındaki toplu konutlarda yaşayan çocukların taşınma sonrasında evlerine karşı duydukları memnuniyet duygusunda önemli oranda bir değişimin gerçekleşmediğini göstermektedir.

Şehir içindeki toplu konutlara taşınan çocukların yaşadıkları eve karşı memnuniyetinde ise önemli oranda bir artış gerçekleşmiştir. Gecekondudan veya gecekondu olmayan bir konuttan geliyor olmak, toplu konutlara taşınan çocukların evlerine karşı besledikleri memnuniyet duygusunda önemli bir etki yaratmamıştır. Mahalle ölçeğinde, formel bir konut alanından şehir içi veya şehir dışındaki toplu konut alanlarına taşınan çocuklarda mahalle memnuniyetinde önemli oranda bir düşüş gerçekleşmiştir. Gecekondu mahallelerinden gelen çocukların mahalle memnuniyetinde ise çocukların taşındıkları proje alanı şehir içi olsun veya olmasın bir değişim gözlemlenmemiştir. Nereden geldiklerine ve nereye taşındıklarına bağlı olarak çocuklar, konut memnuniyetlerindeki değişimin nedenlerini ev ve mahallenin farklı özelliklerine dayandırmıştır. Ne var ki, toplu konutlara taşınma ile birlikte, ev bahçelerinin, araç trafiği yoğun olmayan sokakların, bakkal ve manav gibi geleneksel ticari işletmelerin ve çok-çeşitli etkinlik alanları ve mobilyaya sahip park ve oyun alanlarının kaybolması gibi bazı sorunlar tüm çocuklar tarafından dile getirilen ortak sorunlar olmuştur.

\section{RESIDENTIAL RELOCATION AND CHILDREN'S SATISFACTION WITH MASS HOUSING}

This article investigates the effects of relocation on children's satisfaction with mass housing built in the context of squatter housing regeneration. The results are based on a survey and group interviews with 137 nineto-twelve-year-old children living in three mass housing developments in Ankara, Turkey. At the home level, it was found that while there was no significant change in the satisfaction level of children who moved to an outer-city mass housing development, satisfaction scores significantly increased among children who moved to inner-city estates. Moving from squatter or non-squatter housing did not significantly influence children's dwelling satisfaction. At the neighbourhood level, regardless of their location in the city, satisfaction scores significantly decreased among children who moved from a formal neighbourhood; no significant change was observed among children who moved from a squatter settlement. Depending on where they moved from and their current place of residence, children explained the change in their residential satisfaction by referring to different dwelling and neighbourhood characteristics. Nevertheless, after relocation, all children mentioned some issues, such as the loss of home gardens, low-traffic volume streets, traditional commercial establishments, and parks and playgrounds with diverse activity areas and furniture.

YUCEL CAN SEVERCAN; B.C.P, M.C.P, Ph.D.

He received his bachelor's degree in City and Regional Planning from METU in 2003, master's degree in Urban Design from METU in 2006, and Ph.D. degree from the University of Colorado Denver's Design and Planning program in 2012. His research focuses on various topics including sustainable urban design and urban regeneration, healthy community development, and participatory planning and design. yucelcan@metu.edu.tr 